\title{
Projections of atmospheric mercury levels and their effect on air quality in the United States
}

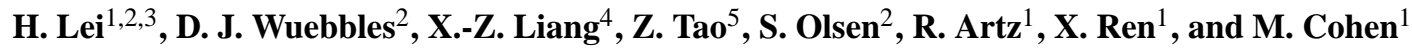 \\ ${ }^{1}$ National Oceanic and Atmospheric Administration (NOAA), Air Resources Laboratory, College Park, Maryland, USA \\ ${ }^{2}$ Department of Atmospheric Sciences, University of Illinois, Urbana, Illinois, USA \\ ${ }^{3}$ Center for Spatial Information Science and Systems, George Mason University, Fairfax, VA, USA \\ ${ }^{4}$ Department of Atmospheric and Oceanic Science, and Earth System Science Interdisciplinary Center, University of \\ Maryland, College Park, Maryland, USA \\ ${ }^{5}$ Universities Space Research Association/NASA Goddard Space Flight Center, Greenbelt, Maryland, USA
}

Correspondence to: H. Lei (hang.lei@noaa.gov)

Received: 13 June 2013 - Published in Atmos. Chem. Phys. Discuss.: 2 August 2013

Revised: 5 December 2013 - Accepted: 13 December 2013 - Published: 23 January 2014

\begin{abstract}
The individual and combined effects of global climate change and emissions changes from 2000 to 2050 on atmospheric mercury levels in the United States are investigated by using the global climate-chemistry model, CAMChem, coupled with a mercury chemistry-physics mechanism $(\mathrm{CAM}-\mathrm{Chem} / \mathrm{Hg})$. Three future pathways from the Intergovernmental Panel on Climate Change (IPCC) Special Report on Emissions Scenarios (SRES) are considered, with the A1FI, A1B and B1 scenarios representing the upper, middle and lower bounds of potential climate warming, respectively. The anthropogenic and biomass burning emissions of mercury are projected from the energy use assumptions in the IPCC SRES report. Natural emissions from both land and ocean sources are projected by using dynamic schemes. TGM concentration increases are greater in the low latitudes than they are in the high latitudes, indicative of a larger meridional gradient than in the present day. In the A1FI scenario, TGM concentrations in 2050 are projected to increase by $2.1-4.0 \mathrm{ng} \mathrm{m}^{-3}$ for the eastern US and 1.4-3.0 $\mathrm{ng} \mathrm{m}^{-3}$ for the western US. This spatial difference corresponds to potential increases in wet deposition of $10-14 \mu \mathrm{g} \mathrm{m}^{-2}$ for the eastern US and 2-4 $\mu \mathrm{g} \mathrm{m}^{-2}$ for the western US. The increase in $\mathrm{Hg}$ (II) emissions tends to enhance wet deposition and hence increase the risk of higher mercury entering the hydrological cycle and ecosystem. In the B1 scenario, mercury concentrations in 2050 are similar to present level concentrations; this finding indicates that the domestic reduction in mercury emissions is essentially counteracted by the effects of climate
\end{abstract}

warming and emissions increases in other regions. The sensitivity analyses show that changes in anthropogenic emissions contribute $32-53 \%$ of projected changes in mercury air concentration, while the independent contribution by climate change and its induced natural emissions change accounts for $47-68 \%$.

\section{Introduction}

The toxic effects of mercury $(\mathrm{Hg})$ are a serious concern to public health. Much scientific effort has been expended to monitor releases of mercury compounds and assess their effects on air quality (USEPA, 2006; Cohen et al., 2007, 2011; NADP, 2008; UNEP, 2008, 2013). Based on its toxicity and present pollution levels, the control of mercury emissions is an international priority (UNEP, 2008), and modeling future changes in pollutants is a useful method to support the formulation of pollution control strategies (Lin et al, 2008; Lei et al., 2012). However, although many modeling studies have investigated the effects of past and present mercury pollution on air quality (Bullock and Brehme, 2002; Cohen et al., 2004; Selin et al., 2008; UNEP, 2008, 2013; Lei et al., 2013b), potential changes in future levels of atmospheric mercury compounds and their uncertainties need further examination. 
Changes in both climate and mercury emissions will determine the atmospheric concentrations of mercury compounds in the future (UNEP, 2013); however, changes in climate alone influence the concentration and composition of atmospheric mercury. Owing to the low vapor pressure of mercury, the atmospheric lifetime and natural emissions of mercury are sensitive to climate change. Previous studies indicate that mercury emissions from soils are affected by changes in temperature and solar radiation (Lindberg et al., 1998; Zhang et al., 2001). Changes in general atmospheric circulation may also change the pathway of the atmospheric transport of mercury (Strode et al., 2007).

Changes in emissions also significantly affect the atmospheric concentrations of mercury compounds (Pan et al., 2010; Lin et al., 2011). The records from glacial ice cores in Wyoming (USGS, 2007) show that rising emissions are the primary factor behind the changes in atmospheric mercury concentration over recent centuries. Modeling studies of preindustrial atmospheric mercury cycles also indicate that industrial emissions of mercury have changed the concentrations of atmospheric mercury compounds (Selin et al., 2007, 2008; Holmes et al., 2009, 2010). Corbitt et al. (2011) found that emissions changes alone can significantly alter the current source-receptor relationships for mercury.

There are considerable uncertainties about climate change, and these will influence mercury pollution in the future according to model simulations (Pan et al., 2008). Recent studies strongly indicate that greenhouse gas emissions from human activities are the primary factor that has driven climate change over the past four decades (IPCC, 2001, 2007). Through the consideration of the uncertainties associated with future social and economic development, the Intergovernmental Panel on Climate Change (IPCC) has developed a series of future emissions scenarios for projecting climate change over this century (IPCC, 2001, 2004, 2007). Many studies of future air quality changes have used these IPCC climate scenarios to assess climate change impacts and estimate associated uncertainties (e.g., Wu et al., 2008; AMAP, 2011; Lei et al., 2013a).

In addition, the uncertainties associated with social and economic development also influence the estimate of future emissions. Mercury is emitted into the atmosphere from both anthropogenic and natural sources. Anthropogenic sources are closely associated with social and industrial development. Global anthropogenic emissions of mercury, which is associated with social and industrial development, were estimated to be $2190 \mathrm{Mg}$ in 2000 (Pacyna et al., 2006). Streets et al. (2009) projected anthropogenic emissions of mercury to 2050 by considering different social development and energy use scenarios.

However, some natural emissions, including land and ocean emissions, are mostly affected by climate. As a result, seasonal variations and spatial differences are significant. These characteristics of natural emissions reduce the effectiveness of the simple scaling method for future projec- tions, which may not correctly present the variations of these characteristics in response to climate change. Thus, natural $\mathrm{Hg}$ emissions are better estimated by using dynamic modeling methods (Poissant and Casimir, 1998; Zhang et al., 2001; Wängberg et al., 2001; Selin et al., 2008; Lei et al., 2013b).

In this study, a global 3-D atmospheric mercury model, termed the Community Atmospheric Model with mercury (CAM-Chem $/ \mathrm{Hg}$ ) (Lamarque et al., 2012), is used to assess the effects of mercury on US air quality from 2000 to 2050. Three distinct climate/emissions pathways from the IPCC Special Report on Emissions Scenarios (SRES) are considered to quantify the range for future climate and full chemical emissions changes, including the A1FI, A1B and B1 scenarios representing the upper, middle and lower bounds of climate change over the coming decades, respectively. The projections of anthropogenic mercury emissions in 2050 are based on the energy use assumed in the specific scenario, while natural emissions are projected through dynamic schemes for mercury emissions driven by future climate and environmental data. The analyses presented herein thus examine both the individual and the combined effects of climate and mercury emissions changes on both surface mercury concentration and deposition over the US.

\section{Model description}

The model used in this study, CAM-Chem $/ \mathrm{Hg}$, is a 3-D atmospheric mercury model based on the CAM-Chem climatechemistry model. The CAM-Chem model considers fully coupled gas-aerosol phase chemistry that originates from the Model of Ozone and Related Chemical Tracers (also known as MOZART) (Horowitz et al., 2003; Tie et al., 2001, 2005; Emmons et al., 2010; Lamarque et al., 2012; Lee et al., 2013). The mercury model can simulate three species of mercury in the atmosphere: elemental mercury $(\operatorname{Hg}(0))$, divalent mercury ( $\mathrm{Hg}(\mathrm{II}))$ and particulate mercury (PHg). Details of the mercury model were previously described by Lei et al. (2013b).

To provide the best estimate of mercury emissions, a land mercury emissions scheme is used to calculate emissions from soil and vegetation as well as re-emissions of newly deposited mercury, which depends on the specific soil Hg storage and model-simulated temperature and radiation over certain locations and times. A simplified air-sea mercury exchange scheme is then used to calculate ocean emissions (Wängberg et al., 2001). Emissions from anthropogenic sources, biomass burning and volcanoes are also considered. The model's mercury chemistry includes the oxidation of gaseous elementary mercury and aqueous mercury. Elemental mercury is oxidized by ozone and the oxidation is temperature-dependent. Oxidations of mercury by $\mathrm{OH}, \mathrm{H}_{2} \mathrm{O}_{2}$ and chlorine are also included. The previous sensitivity study incorporating both an ozone oxidation mechanism and a bromine oxidation mechanism in CAM-Chem $/ \mathrm{Hg}$ 
Table 1. CAM-Chem/Hg Runs in this study for specific climate and emissions scenarios.

\begin{tabular}{llll}
\hline Runs & Meteorology $^{\mathrm{a}}$ & $\begin{array}{l}\text { Land and Ocean } \\
\text { Hg Storage }^{\mathrm{b}}\end{array}$ & $\begin{array}{l}\text { Anthropogenic } \\
\text { Emissions }^{\mathrm{c}}\end{array}$ \\
\hline (1) Present & CESM3: 2000 & 2000 & 2000 \\
(2) 2050A1FI & CESM3: 2050 A1FI & 2050 A1FI & 2050 A1FI \\
(3) 2050A1B & CESM3: 2050 A1B & 2050 A1B & 2050 A1B \\
(4) 2050B1 & CESM3: 2050 B1 & 2050 B1 & 2050 B1 \\
(5) Climate2050 A1FI & CESM3: 2050 A1FI & Present & Present \\
(6) Climate2050 A1B & CESM3: 2050 A1B & Present & Present \\
(7) Climate2050 B1 & CESM3: 2050 B1 & Present & Present \\
\hline
\end{tabular}

${ }^{a}$ Meteorology for future are projected by CESM3 system following specific scenario. ${ }^{b}$ Future storage change consider the accumulations of net deposition following specific scenario. ${ }^{\mathrm{c}}$ Anthropogenic emissions of $\mathrm{Hg}$ are projected following specific scenario.

shows too much oxidation of Gaseous Elemental Mercury (GEM) and thus overestimates the wet deposition of Reactive Gaseous Mercury (RGM) (Lei et al., 2013b). Therefore, the bromine oxidation mechanism is excluded. The aqueous reduction of mercury species is also considered in the model. After balancing all the chemical reactions, the transport and deposition of mercury are calculated in each time step.

In this study, emissions of all chemical components used by the CAM-Chem/ $\mathrm{Hg}$ model are projected to 2050. We first project emissions of chemicals other than mercury species from 2000 to 2050 following the IPCC SRES, as previously carried out for the study of future ozone levels (Lei et al., 2012). Then, anthropogenic emissions of mercury are projected to 2050 based on the energy use assumptions made in the IPCC SRES report (IPCC, 2001). These projections follow the IPCC's A1FI, A1B and B1 scenarios and use the method introduced by Streets et al. (2009). These scenarios are developed in the IPCC Fourth Assessment Report to assess possible future scientific, technical and socioeconomic development concerning the potential effects of climate change. The A1FI scenario emphasizes the intensive use of fossil fuel energy. The A1B scenario balances all energy sources. The B1 scenario considers a clean and ecologically friendly energy structure in the future. Natural emissions from both land and ocean sources in 2050 are calculated by using dynamic schemes built in the atmospheric mercury model (Lei et al., 2013b). Biomass burning emissions of $\mathrm{Hg}$ in 2050 are also projected by using the method introduced by Streets et al. (2009).

In order to understand how changes in climate or anthropogenic emissions independently contribute to future changes in the concentrations of atmospheric mercury compounds, a series of sensitivity experiments that consider climate change alone while keeping emissions unchanged (i.e., industrial emissions and land/ocean storage at the presentday level) are conducted for the three future scenarios (B1, A1B and A1FI). "Climate change only" means the total effects including (1) climate change caused natural emissions change in the future without considering possible changes in mercury accumulations in land/ocean reservoirs, (2) caused changes in gaseous and aqueous $\mathrm{Hg}$ chemical reactions and (3) caused changes in the transport and deposition of mercury species. The difference between these experiments and the present-day result represents the independent effect of climate change, while the difference between these experiments and future projections (climate plus emissions change results) for 2050 depicts the independent effect of anthropogenic emissions change.

The CAM-Chem $/ \mathrm{Hg}$ model is driven by meteorological fields derived from the Community Climate System Model (version 3). The meteorology fields derived for the present and future atmosphere by using this model are archived in $6 \mathrm{~h}$ temporal resolution, including winds, temperature, pressure, humidity and solar radiation. Future meteorology fields are derived following specific IPCC scenarios (http://www. cesm.ucar.edu/experiments/ccsm3.0/). Simulations are performed with a $30 \mathrm{~min}$ time step and a horizontal resolution of $1.9^{\circ} \times 2.5^{\circ}$ with 26 vertical levels from the surface $(1000 \mathrm{hPa})$ to the 3 millibar level ( $\sim 40 \mathrm{~km}$ altitude). Previous tests have demonstrated that roughly a 6-month spinup is enough for CAM-Chem to minimize the influence of the initial conditions. In this study, each case was run for 5 yr (2048-2052) following a year of model spin-up. Unless noted otherwise, all results discussed are based on $5 \mathrm{yr}$ averages. The modeled concentrations of mercury compounds were obtained at $1 \mathrm{~h}$ intervals. All runs based on CAM$\mathrm{Chem} / \mathrm{Hg}$ in this study are summarized in Table 1 including the detailed initial values for meteorological fields, natural $\mathrm{Hg}$ storage and anthropogenic emissions of $\mathrm{Hg}$.

\section{Projection of future $\mathrm{Hg}$ emissions}

Emissions of mercury compounds for 2050 are derived in three ways based on the source type and dynamic emissions approaches used in CAM-Chem. 


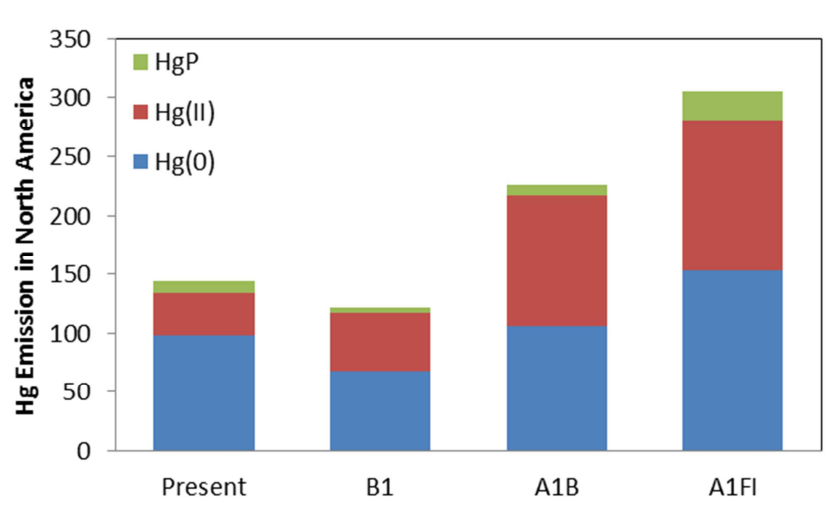

Fig. 1. Emissions of three mercury species from anthropogenic sources for 2000 (present) and 2050 in North America (Units: tons $\mathrm{yr}^{-1}$ ). Emissions for 2050 are displayed in three future climate change scenarios: B1, A1B, and A1F1, representing the lower, middle and upper bounds of potential climate warming, respectively.

\subsection{Industrial emissions}

To examine the industrial emissions of mercury in 2050, we use the projected results and scaling rates for the A1B and B1 scenarios presented by Streets et al. (2009). For the A1FI scenario, we project mercury emissions by using the same method as deployed for calculating energy use information in the IPCC SRES A1FI scenario (RIVM, 2001). The A1FI scenario is characterized by a rapid increase in the production of fossil fuel energy and economic growth. We assume that no significant advance is made over the reported $\mathrm{Hg}$ removal levels in the A1FI scenario. The rates of the implementation of Flue Gas Desulphurization (FGD) by 2050 in coal-fired power plants for the A1 series scenarios are the same as referenced in RIVM (2001). Of the factors that affect mercury emissions, the use of coal, oil and natural gas in 2050 in the A1FI scenario is assumed to increase more than that in the A1B scenario. The final estimate of the amount of mercury emissions in each IPCC SRES region is calculated based on the FGD and estimated energy growth in RIVM (2001). As introduced in Lei et al. (2013b), we adopt current (i.e., year 2000) anthropogenic emissions of mercury directly from those prepared by Pacyna et al. (2006). This emissions level is used as the base inventory to carry out the projection.

The resulting emissions inventories used in this study are summarized in Table 2. Global total Hg emissions are expected to increase in the future. The range of annual global mercury emissions in 2050 is projected to be $2390-5990 \mathrm{Mg}$, an increase of $9 \%$ to $173 \%$ over total emissions in 2000 . The main factor affecting $\mathrm{Hg}$ emissions is the increase in fossil fuel usage. Asia has the largest emissions increase, corresponding to its large population and rising energy demand.

Figure 1 shows the present and projected mercury emissions from anthropogenic sources for North America. Total mercury emissions in 2050 increase to $305.7 \mathrm{Mg} \mathrm{yr}^{-1}$ in the
A1FI scenario and to $225.9 \mathrm{Mg} \mathrm{yr}^{-1}$ in the A1B scenario, but decrease to $121.9 \mathrm{Mg} \mathrm{yr}^{-1}$ in the $\mathrm{B} 1$ scenario relative to the present value of $145.8 \mathrm{Mg} \mathrm{yr}^{-1}$. The most significant characteristic is that the amount and proportion of reactive mercury $(\mathrm{Hg}(\mathrm{II}))$ in total mercury emissions will increase, whereas the proportion of elemental mercury $(\mathrm{Hg}(0))$ will decrease by 2050 in all future scenarios. The global shares of primary emitted mercury species are $67 \%$ for $\mathrm{Hg}(0), 25 \%$ for $\mathrm{Hg}(\mathrm{II})$ and $7 \%$ for $\mathrm{PHg}$ at present (Pacyna et al., 2006). These change in 2050 to $56 \%$ for $\mathrm{Hg}(0), 40 \%$ for $\mathrm{Hg}(\mathrm{II})$ and $4 \%$ for PHg in the B1 scenario, to $47 \%, 49 \%$ and $4 \%$ in the A1B scenario (Streets et al., 2009) and to $49 \%, 43 \%$ and $8 \%$ in the A1FI scenario. Owing to the implementation of FGD, this shift from $\mathrm{Hg}(0)$ (reduced) to $\mathrm{Hg}$ (II) (oxidized) may reduce the long-range transport but significantly increase the local deposition of mercury.

\subsection{Biomass burning and volcanic emissions}

Biomass burning emissions are specified as monthly means from the IPCC estimate of biomass burned and the IMAGE projection of managed forests for a typical year. The approach used and $\mathrm{Hg}$ emissions factors as a function of vegetation types are adopted from Streets et al. (2009). The amount of open biomass burning is adopted from the IPCC (2001) projections, which are scenario-specific. Wildfire contribution to biomass emissions is estimated as a proportion of changes in mature forest area (IPCC, 2001; Streets et al., 2009). The IPCC projections of grassland and crop residue burning (human activities) are also used. The global estimated total mercury emissions from biomass burning for 2000 are $600 \mathrm{Mg} \mathrm{yr}^{-1}$. This figure is projected to be $670 \mathrm{Mg} \mathrm{yr}^{-1}$ in 2050 in the A1FI scenario, $570 \mathrm{Mg} \mathrm{yr}^{-1}$ in 2050 in the A1B scenario and $447 \mathrm{Mg} \mathrm{yr}^{-1}$ in 2050 in the B1 scenario. These estimates are comparable with previous results on present emissions or future projections of mercury emissions from biomass burning (Streets et al., 2005).

Volcanic emissions of mercury are estimated based on sulfur emissions from volcanic sources in the Global Emissions InitiActive inventory. We use an $\mathrm{Hg} / \mathrm{SO}_{2}$ proportion of $1.5 \times 10^{-6}$ for all volcanic eruptions (Aiuppa et al., 2007; Witt et al., 2008) in volcanic ash and the well-established $\mathrm{SO}_{2}$ emissions (http://www.geiacenter.org) to indirectly calculate mercury emissions. A similar method has been used in previous studies (e.g., Ferrara et al., 2000; Nriagu and Becker, 2003; Pyle and Mather, 2003). The present estimate of mercury emissions from volcanoes is $\sim 500 \mathrm{Mg} \mathrm{yr}^{-1}$. This value is considered to be an historical average for the eruptions of active volcanoes and slow emissions from nonerupting stable volcanoes (http://www.geiacenter.org), and it is assumed to remain unchanged under future conditions. 
Table 2. Anthropogenic emissions of $\mathrm{Hg}$ in 2000 and 2050 for each world region $\left(\mathrm{Mg} \mathrm{yr}^{-1}\right)$ based on SRES scenarios.

\begin{tabular}{lrrrrrr}
\hline Scenario & $\begin{array}{r}\text { North } \\
\text { American }\end{array}$ & $\begin{array}{r}\text { Asia \& } \\
\text { Oceania }\end{array}$ & $\begin{array}{r}\text { Europe \& } \\
\text { Mid East }\end{array}$ & Africa & $\begin{array}{r}\text { Central \& } \\
\text { South America }\end{array}$ & World \\
\hline $2000^{\text {(a) }}$ & 145.8 & 1305.9 & 247.8 & 398.4 & 92.1 & 2189.9 \\
$2050 \mathrm{~A} 1 \mathrm{FI}$ & 305.7 & 3307.1 & 861.3 & 789.2 & 720.4 & 5983.7 \\
$2050 \mathrm{~A} 1 \mathrm{~B}^{\mathrm{b}}$ & 225.9 & 2970.0 & 676.5 & 509.6 & 437.6 & 4855.6 \\
$2050 \mathrm{B1}^{\mathrm{b}}$ & 121.9 & 1208.9 & 358.1 & 357.0 & 340.4 & 2386.2 \\
\hline
\end{tabular}

${ }^{\mathrm{a}}$ Results from Pacyna et al., 2006; ${ }^{\mathrm{b}}$ projection results from Streets et al., 2009.

\subsection{Natural emissions from land and oceans}

In order to project land and ocean emissions to 2050, we modify the dynamic emissions schemes for mercury developed in the CAM-Chem/Hg model (Lei et al., 2013b) in order to include the storage change in surface reservoirs. Surface $\mathrm{Hg}$ storage and climate are two of the major determining factors of $\mathrm{Hg}$ emissions. Storage change directly affects the amount of available mercury compounds. Climate change, especially changes in surface temperature, net solar radiation and surface wind, directly affects $\mathrm{Hg}$ emissions from land and oceans.

Surface storage change is related to the net deposition flux above the land and oceans. Anthropogenic and volcanic sources bring fresh mercury species into the biogeochemical cycle. Mercury storage in 2050 is determined by the net surface accumulation of fresh mercury in the past. Therefore, the change in surface $\mathrm{Hg}$ storage by 2050 should be the net accumulations of the fresh mercury emitted in future years before 2050. The latest estimate of present land mercury storage is approximately $240000 \mathrm{Mg}$ with a total deposition of $3260 \mathrm{Mg} \mathrm{yr}^{-1}$ and total land emissions of $2900 \mathrm{Mg} \mathrm{yr}^{-1}$ (Smith-Downey et al., 2010). This estimation suggests a net new mercury increase in the surface land reservoir of $360 \mathrm{Mg} \mathrm{yr}^{-1}$, which accounts for $13 \%$ of total net mercury emissions (anthropogenic + volcanic: $2770 \mathrm{Mg} \mathrm{yr}^{-1}$ ). Based on the CAM-Chem $/ \mathrm{Hg}$ simulations, the estimate of a net increase in the atmospheric reservoir for the present atmosphere shows that approximately $1 \%$ of newly emitted mercury will stay in the atmosphere. The rest $(86 \%)$ of the fresh mercury is deposited into the surface oceans. We assume that these partitioning ratios of new mercury are constant from 2000 to 2050. By using this linkage between surface Hg storage change and fresh mercury emissions, the dynamic emissions schemes in the CAM-Chem/Hg model can calculate future emissions fluxes.

The land emissions scheme is thus modified by considering a change in land mercury storage. The modified scheme is

$$
\begin{array}{r}
F_{2}=F_{1} \exp \left[-1.1 \times 10^{4}\left(\frac{1}{T_{\mathrm{s}}}-\frac{1}{T_{0}}\right)\right] \\
\exp \left[1.1 \times 10^{3}\left(R_{\mathrm{S}}-R_{0}\right)\right] \times C_{i}
\end{array}
$$

where $R_{\mathrm{S}}$ is surface solar radiation and $T_{\mathrm{S}}$ is surface skin temperature. $R_{0}$ is the reference surface solar radiation with a value of $340 \mathrm{~W} \mathrm{~m}^{-2}$. $T_{0}$ is the reference surface temperature with a value of $288 \mathrm{~K} . F_{1}$ is the standard emissions dataset. $C_{i}$ is the enrichment factor following each scenario. $C_{i}$ is calculated as follows:

$C_{i}=\frac{S_{\mathrm{p}}+\alpha n\left(E_{\mathrm{p}}+E_{\mathrm{f}}\right) / 2}{S_{\mathrm{p}}}$

where $S_{\mathrm{p}}$ is the present land storage of mercury $(240000 \mathrm{Mg}) . E_{\mathrm{p}}$ is the present amount of total new mercury emissions. $E_{f}$ is the projected amount of new mercury emissions. The value of $\alpha(0.13)$ is determined by the proportion of new mercury in the land reservoir. We assume that the net increase in new mercury follows a linear trend. The parameter $n$ is the number of years relative to 2000 . Here, the value of $n$ is 50 .

The ocean emissions scheme is modified by considering the change in mercury concentration in the ocean mixing layer. The modified simple model is

$F=K_{\mathrm{w}}\left(\left(C_{\mathrm{w}}+m_{i}\right)-\frac{C_{\mathrm{a}}}{H^{\prime}}\right)$

where $m_{i}$ is the scenario-specific change in mercury concentration in the ocean mixing layer based on presentday values. Other variables and calculations follow Lei et al. (2013b). As shown by Soerensen et al. (2010), $40 \%$ of net deposition will enter the subsurface water that will not re-emit into the atmosphere, while $60 \%$ of the net deposition of new mercury will stay in the ocean mixing layer (Strode et al., 2007). $m_{i}$ is calculated by the following scheme:

$m_{i}=\frac{60 \% \beta n\left(E_{\mathrm{p}}+E_{\mathrm{f}}\right) / 2}{71 \% \times 4 \pi R^{2} \times d}$

where $\beta$ (0.86) is the proportion of new mercury in the surface ocean reservoir, which is estimated based on the present distribution of mercury deposition from anthropogenic sources. $E_{\mathrm{p}}$ is the present amount of total new mercury emissions. $E_{\mathrm{f}}$ is the projected amount of new mercury emissions. $n$ is the number of years projected away from the present and $R$ is the radius of the Earth. The factor $71 \%$ accounts for the percentage of the Earth's surface covered by 

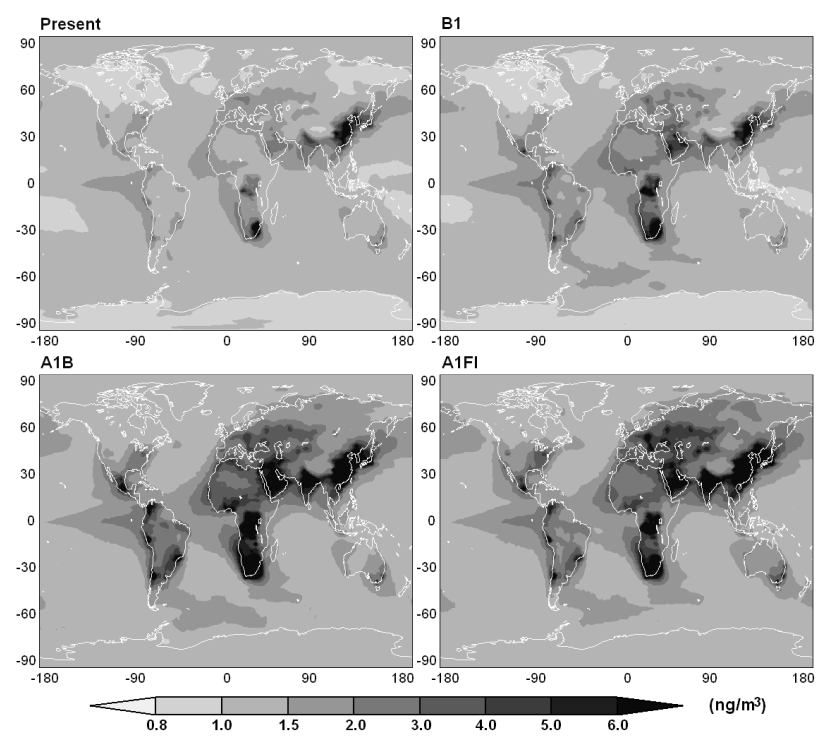

Fig. 2. Annual mean of global surface TGM concentrations for 2000 (present) and for 2050 under the B1, A1B and A1FI scenarios as simulated by the CAM-Chem/Hg model.

oceans. The parameter $d$ is the depth of the ocean mixing layer. We set this to $50 \mathrm{~m}$ as an average depth and assume that $\mathrm{Hg}$ is evenly mixed in the ocean mixing layer (Soerensen, et al., 2010; Fisher et al., 2012).

\section{Global mercury pollution in 2050}

Figure 2 shows the global annual mean surface concentrations of total gaseous mercury (TGM: $\mathrm{Hg}(0)$ and $\mathrm{Hg}(\mathrm{II})$ in the gaseous phase) for the present day and for 2050 in the B1, A1B and A1FI scenarios. The changes in the spatial patterns of TGM show an overall worsening situation of mercury pollution following the increasing use of fossil fuel energy (B1 to A1FI), except for the US region in the B1 scenario. The annual average TGM level by 2050 has increased by $10 \%$ above the present level in the B1 scenario in which total global emissions increase in developing countries and decrease in developed countries. The temperature increase in scenario B1 is approximately $1^{\circ} \mathrm{C}$. A higher temperature will accelerate the mercury cycle and lead to more surface mercury being emitted into the atmosphere. The concentration increases in the A1FI and A1B scenarios mostly occur over land. The increases in Asia and Africa are especially large. The average concentrations over Asian industrial regions are above $6.0 \mathrm{ng} \mathrm{m}^{-3}$. The TGM concentrations over the rest of the world also increase as a result of higher local emissions and the enhanced long-range transport of mercury compounds from major mining industrial regions (Corbitt et al., 2011).

Figure 3 shows the zonal average of surface TGM concentrations for the present day and for 2050 according to these

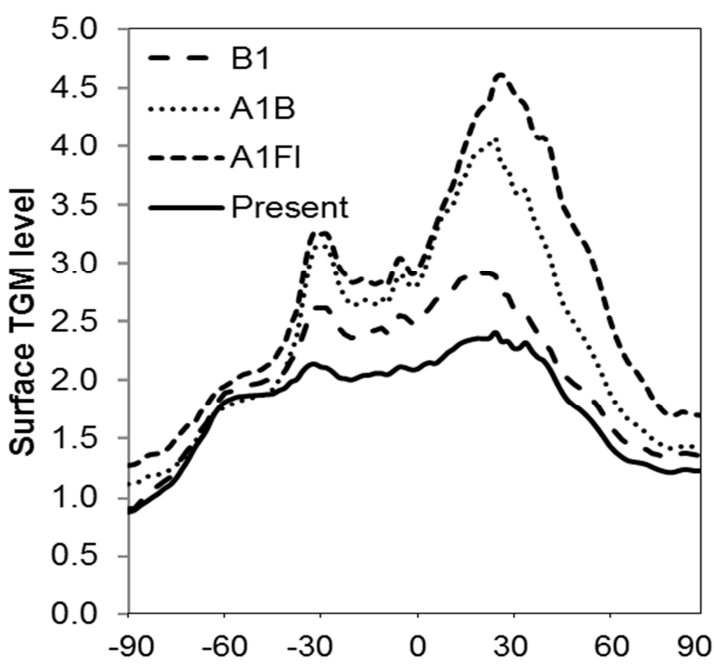

Fig. 3. Zonal averaged surface TGM concentrations for 2000 (present) and for 2050 under the B1, A1B and A1FI scenarios as simulated by the CAM-Chem/Hg model. (Units: $\mathrm{ng} \mathrm{m}^{-3}$ )

three scenarios. Generally, present and future zonal average concentrations have a similar spatial pattern, but the interhemispheric difference in the future is much larger compared with that in present. The zonal average concentration peaks at the mid-latitude of the Northern Hemisphere, where industrial sources are spreading. The average concentrations in the Southern Hemisphere are also maximized at the midlatitude. This result may be caused by the mining industries in southern Africa. The estimated mercury concentration in 2050 in the A1FI scenario shows a significant increase (up to $2.4 \mathrm{ng} \mathrm{m}^{-3}$ ) in the middle and low latitudes. The peak value in 2050 is approximately twice as much as the presentday concentration. The peak value in the A1B scenario is approximately $0.5 \mathrm{ng} \mathrm{m}^{-3}$ lower than the peak value in the A1FI scenario. The concentration change in the $\mathrm{B} 1$ scenario in the middle and low latitudes is up to $0.5 \mathrm{ng} \mathrm{m}^{-3}$ higher than the present-day level. The concentration changes in the high latitudes are much smaller than those in the middle or low latitudes. At the high latitudes of the Southern Hemisphere, where fewer industrial and human activities occur, the average concentration change is as low as $0.2 \mathrm{ng} \mathrm{m}^{-3}$.

\section{Effect of mercury on US air quality}

US air quality is affected by domestic emissions and the long-range transport of mercury from other regions. Previous studies have examined the effect of mercury on US air quality based on regional modeling perspectives (Bullock and Brehme, 2002; Holloway et al., 2012). By better calculating the remote impacts, this study examines the effects on present and future US air quality from a global modeling perspective. Figure 4 shows the annual average surface air concentrations of TGM for 2000 and 2050 in the B1, A1B 


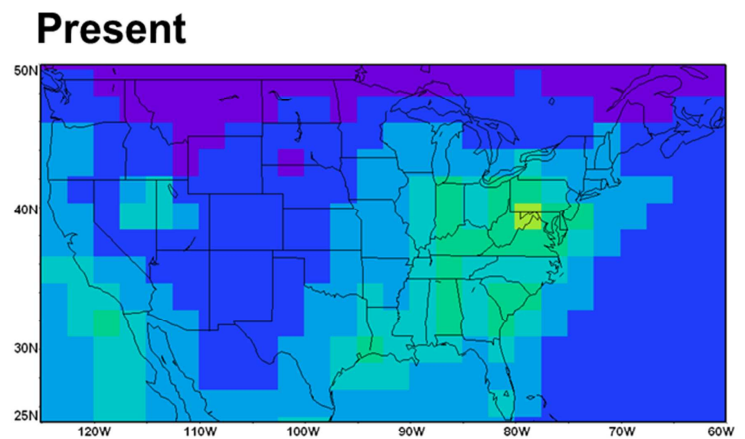

A1B-2050

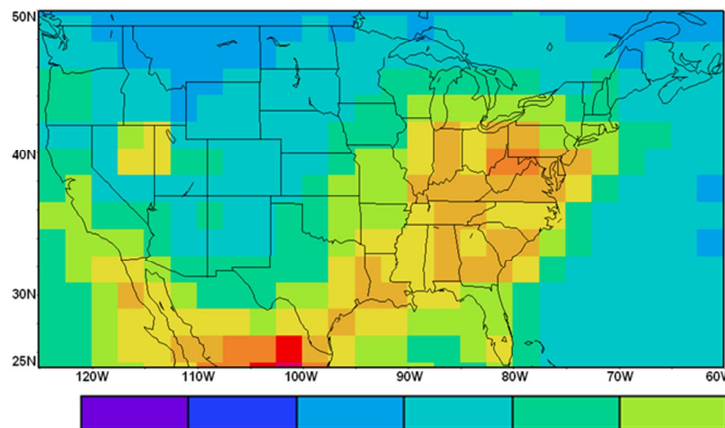

\section{B1-2050}

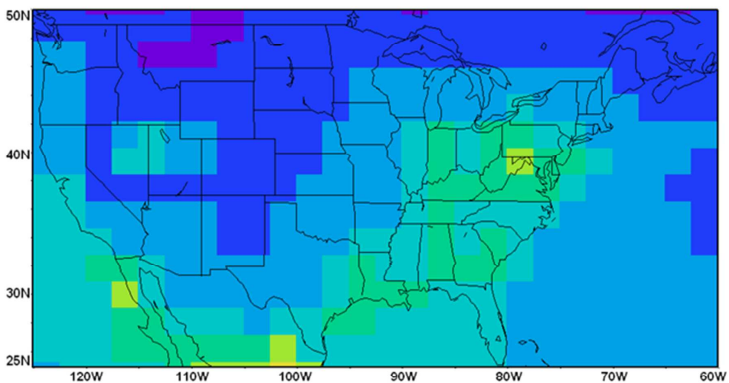

A1FI-2050

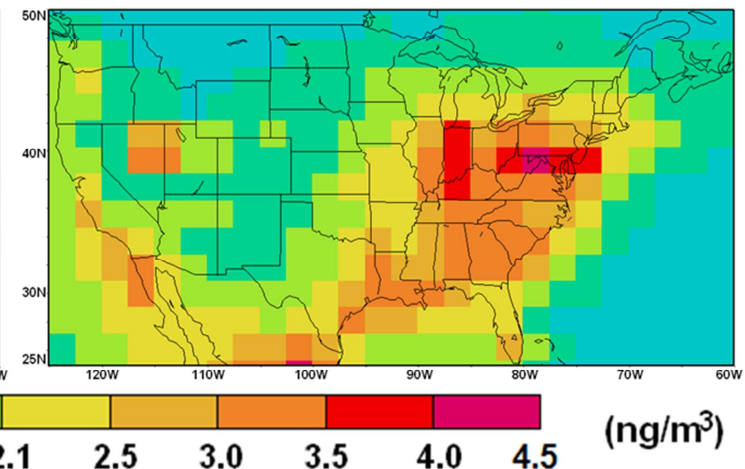

Fig. 4. Annual mean of simulated surface TGM concentrations over the continental US by CAM-Chem/Hg for 2000 (present) and for 2050 under the B1, A1B and A1FI scenarios.

and A1FI scenarios in the contiguous US. The spatial pattern of TGM concentrations exhibits high values in coastal areas and the eastern US, where industrial emissions are high. The results show that annual average TGM levels are projected to change little by 2050 in the B1 scenario as a result of the compensating effects of the emissions decrease and temperature increase of approximately $1^{\circ} \mathrm{C}$. Increased $\mathrm{Hg}$ emissions in neighboring countries also contribute to the TGM concentration level seen for the US (UNEP, 2013). By 2050 in the A1B scenario, the annual average TGM level is projected to have risen, with increases up to $1.4 \mathrm{ng} \mathrm{m}^{-3}$ over the eastern US The TGM level in 2050 in the A1FI scenario shows the largest increase (up to $2.2 \mathrm{ng} \mathrm{m}^{-3}$ ) in response to the largest rise in mercury emissions and the high degree of climate warming.

The oxidation of elemental mercury in the CAM$\mathrm{Chem} / \mathrm{Hg}$ model is next examined under each scenario by comparing the RGM/GEM ratio. Figure 5 shows the seasonal variation in monthly averaged RGM/GEM ratios over the contiguous US. The result shows that the ratio is low during wintertime, but peaks during the summertime. Previous studies have suggested that this ratio is highly related to the mercury oxidation mechanism used in models (Timonen et al., 2013). In CAM-Chem $/ \mathrm{Hg}$, the ozone-OH oxidation mechanism (Lei et al., 2013b) primarily adopts a temperature-dependent reaction coefficient for the ozone ox-

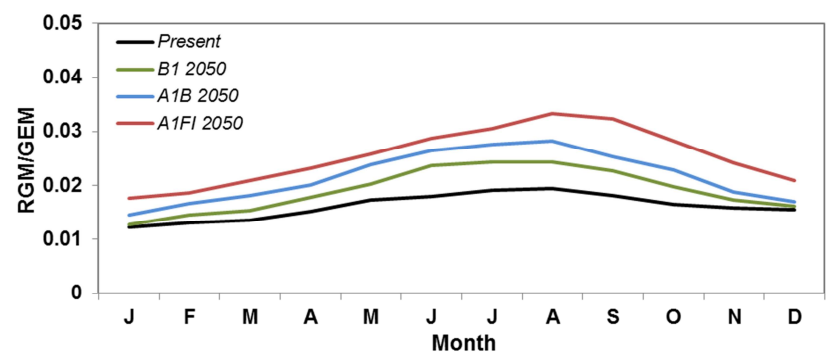

Fig. 5. Simulated oxidation of elemental $\mathrm{Hg}$ over the contiguous US. (Average over the region $25-50^{\circ} \mathrm{N}, 130-60^{\circ} \mathrm{W}$.)

idation reaction. As a result, oxidation is not only affected by the available GEM and ozone concentrations but also positively correlated to temperature rising. In addition, the temperature-caused changes in ozone formation also contribute to GEM oxidation.

The comparison between scenarios also shows the temperature effect. For the present day, the RGM/GEM ratio generally stays below 0.02 in the CAM-Chem/Hg model, which agrees with the results of previous measurements (Jaffe et al., 2005; Chand et al., 2008; Timonen et al., 2013). With the temperature rising, the RGM / GEM ratios increase by 2050 , which is distinct in summertime and weak in wintertime. The variations in the ratios by 2050 also show some difference 

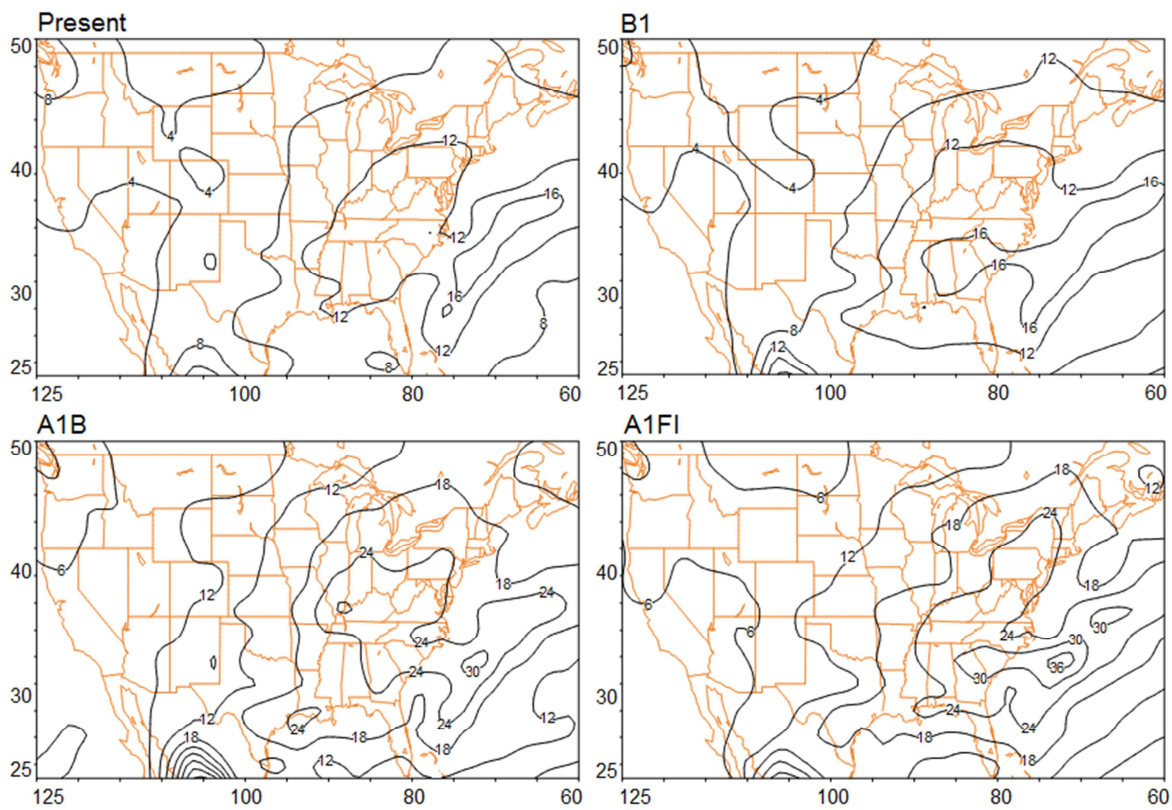

Fig. 6. Simulated annual mercury wet deposition for 2000 and for 2050 under the B1, A1B, and A1FI scenarios. (Units: $\mu \mathrm{g} \mathrm{m}^{-2}$ )

in seasonality that may be caused by factors other than the warming gradients under different scenarios. Changes in other atmospheric chemicals can modify the reaction environment. Meteorology would be a key factor in affecting the RGM / GEM ratio (Timonen et al., 2013) by changing transport and deposition processes.

The wet deposition of mercury increases in the future but these rises are not enough to set off emissions increases. Therefore, US air quality will worsen in the future. Figure 6 shows the simulated annual mean wet deposition of mercury in 2000 and 2050. Their spatial patterns are similar. In general, peak wet deposition is located in the southeast, especially the coastal areas of Georgia and South Carolina. This pattern is affected by the amount of precipitation and atmospheric concentration of mercury. The present annual wet deposition of mercury is above $12 \mu \mathrm{g} \mathrm{m}^{-2}$ for the eastern US and approximately $4 \mu \mathrm{g} \mathrm{m}^{-2}$ for the western US. By 2050 in the B1 scenario, the wet deposition shows an increase of 1$2 \mu \mathrm{g} \mathrm{m}^{-2}$ for the eastern US, while there is little change for the western US. In the A1B scenario, the midwest is projected to have a wet deposition of $18-24 \mu \mathrm{g} \mathrm{m}^{-2}$, which is as strong as the present deposition in the southeast. The increase in the eastern US is $6-12 \mu \mathrm{g} \mathrm{m}^{-2}$ compared with $2-4 \mu \mathrm{g} \mathrm{m}^{-2}$ in the western US. The annual wet deposition in 2050 in the A1FI scenario increases by $10-14 \mu \mathrm{g} \mathrm{m}^{-2}$ for the eastern US and $2-4 \mu \mathrm{g} \mathrm{m}^{-2}$ for the western US.

\section{Effects of climate change and anthropogenic emissions on US mercury levels}

For the projection of 2050 mercury effects considering both climate and anthropogenic emissions changes, Fig. 7 shows the simulated average concentrations of annual mean surface mercury species over the continental US for 2000 and 2050 in the B1, A1B and A1FI scenarios. In the following analysis, the concentration unit is $\mathrm{n} \mathrm{m}^{-3}$ for elemental mercury and $\mathrm{pg} \mathrm{m}^{-3}$ for reactive gaseous mercury and particulate mercury. The bars represent the mercury concentration averaged over the US and the lines show the ranges (i.e., minimum and maximum mercury concentrations in the US). As discussed in the previous section, the concentration of each mercury species increases. In the A1FI scenario, the increase by 2050 is the greatest due to the continuous rise in anthropogenic emissions and high warming. Although elemental mercury remains the main chemical form of mercury in the atmosphere, the relative increase in the concentrations of reactive gaseous mercury is the largest in all three scenarios. This results from the increase in the emissions of reactive gaseous mercury and the accelerated oxidation of elemental mercury at a higher temperature, as the reaction coefficient for the elemental mercury oxidation by ozone increases as temperatures rise (Rutter et al., 2012).

Figure 8 shows the results of the sensitivity experiments of climate change alone, where anthropogenic emissions and the land and ocean storage of mercury are all kept at the present-day level. Compared with the present-day concentration of each mercury species, the differences among the three scenarios are small, which indicates a limited effect of 
Table 3. Changes in average surface concentrations of $\mathrm{Hg}$ species over the US in 2050 resulting from climate change and anthropogenic emission changes

\begin{tabular}{llllr}
\hline Scenario & $\Delta T$ & Effect of Change in & $\mathrm{Hg}$ Species & $\Delta \mathrm{Hg}\left(\mathrm{unit}^{\mathrm{a}, \mathrm{b}}\right)$ \\
\hline B1 & $+1.0^{\circ} \mathrm{C}$ & Climate & $\mathrm{Hg}(0)$ & 0.14 \\
& & (Climate2050 - Present) & $\mathrm{Hg}(\mathrm{II})$ & 4.7 \\
& & $\mathrm{PHg}$ & 3.3 \\
& & Anthropogenic Emission & $\mathrm{Hg}(0)$ & -0.05 \\
& & $(2050-$ Climate2050) & $\mathrm{Hg}(\mathrm{II})$ & 9.6 \\
& & $\mathrm{PHg}$ & -0.6 \\
\hline A1B & $+1.4^{\circ} \mathrm{C}$ & Climate & $\mathrm{Hg}(0)$ & 0.45 \\
& & (Climate2050 - Present) & $\mathrm{Hg}(\mathrm{II})$ & 8.9 \\
& & $\mathrm{PHg}$ & 6.8 \\
& & Anthropogenic Emission & $\mathrm{Hg}(0)$ & 0.77 \\
& & & $\mathrm{Hg}(\mathrm{II})$ & 27.7 \\
& & $\mathrm{PHg}$ & 2.1 \\
\hline A1FI & $+1.7^{\circ} \mathrm{C}$ & Climate & $\mathrm{Hg}(0)$ & 0.63 \\
& & (Climate2050 - Present) & $\mathrm{Hg}(\mathrm{II})$ & 11.6 \\
& & $\mathrm{PHg}$ & 9.8 \\
& & Anthropogenic Emission & $\mathrm{Hg}(0)$ & 1.05 \\
& & & $\mathrm{Hg}(\mathrm{II})$ & 33.0 \\
& & & $\mathrm{PHg}$ & 8.0 \\
\hline
\end{tabular}

$\Delta T$ : global average temperature change in 2050 compared to $2000 .{ }^{\mathrm{a}} \mathrm{Hg}(0)$ in units of $\mathrm{ng} \mathrm{m}{ }^{-3} \cdot{ }^{\mathrm{b}} \mathrm{Hg}(\mathrm{II})$ and $\mathrm{PHg}$ are in units of $\mathrm{pg} \mathrm{m}^{-3}$.

climate change alone on mercury pollution. Table 3 summarizes the changes in the surface concentrations of $\mathrm{Hg}$ species over the US in 2050 caused by climate change or anthropogenic emissions changes. The average temperature increases in 2050 in the $\mathrm{B} 1, \mathrm{~A} 1 \mathrm{~B}$ and A1FI scenarios are $1.0^{\circ} \mathrm{C}, 1.4^{\circ} \mathrm{C}$ and $1.7^{\circ} \mathrm{C}$, respectively. $\Delta \mathrm{Hg}$ shows the individual contribution of climate change alone or anthropogenic emissions change alone to the concentrations of mercury species averaged over the US in 2050. By modifying the mercury chemistry and natural emissions, climate change individually contributes to the surface concentration of elemental mercury by $0.14 \mathrm{ng} \mathrm{m}^{-3}$ in the B1 scenario, $0.45 \mathrm{ng} \mathrm{m}^{-3}$ in the A1B scenario and $0.63 \mathrm{ng} \mathrm{m}^{-3}$ in the A1FI scenario. By contrast, the contributions to the concentrations of reactive gaseous mercury are $4.7 \mathrm{pg} \mathrm{m}^{-3}, 8.9 \mathrm{pg} \mathrm{m}^{-3}$ and $11.6 \mathrm{pg} \mathrm{m}^{-3}$ and those of particulate mercury are $3.3 \mathrm{pg} \mathrm{m}^{-3}$, $6.8 \mathrm{pg} \mathrm{m}^{-3}$ and $9.8 \mathrm{pg} \mathrm{m}^{-3}$. The increase in temperature enhances emissions from land and ocean sources and accelerates the oxidation of elemental mercury. Therefore, both $\mathrm{Hg}(\mathrm{II})$ and $\mathrm{PHg}$ show relatively high increases in concentration compared with $\mathrm{Hg}(0)$.

The effect of changes in anthropogenic emissions is calculated as the difference between the 2050 simulations with changes in climate plus emissions and the simulations with only climate change. The changes in anthropogenic emissions account for the increases in emissions due to the increased storage of mercury in land and ocean reservoirs, which mainly results from human activities. The decrease in anthropogenic emissions in the $\mathrm{B} 1$ scenario reduces the concentrations of elemental mercury by $0.04 \mathrm{ng} \mathrm{m}^{-3}$, whereas the concentration of reactive gaseous mercury increases it by approximately $9.55 \mathrm{pg} \mathrm{m}^{-3}$. The proportion of $\mathrm{Hg}(\mathrm{II})$ relative to total emissions also increases, resulting in a net rise in $\mathrm{Hg}(\mathrm{II})$ emissions in 2050 in the B1 scenario. The concentration of particulate mercury in 2050 is reduced by $0.6 \mathrm{pg} \mathrm{m}^{-3}$ in response to changes in anthropogenic emissions. In the A1B scenario, the change in the chemical partitioning of mercury emissions results in a significant decrease in elemental mercury and an increase in reactive gaseous mercury in 2050. The contribution of changes in anthropogenic emissions to the concentration of elemental mercury is approximately $0.77 \mathrm{ng} \mathrm{m}^{-3}$, while the contribution to $\mathrm{Hg}$ (II) is $27.7 \mathrm{pg} \mathrm{m}^{-3}$ and that to $\mathrm{PHg}$ is $2.1 \mathrm{pg} \mathrm{m}^{-3}$. The contribution to $\mathrm{Hg}$ (II) is much higher than that at present. This trend continues in the A1FI case, where the contribution of changes in anthropogenic emissions to the concentration of elemental mercury is approximately $1.05 \mathrm{ng} \mathrm{m}^{-3}$, while it is $33.0 \mathrm{pg} \mathrm{m}^{-3}$ for $\mathrm{Hg}$ (II) and $8.0 \mathrm{pg} \mathrm{m}^{-3}$ for PHg.

The uncertainty in the above results and their significance depend on the model biases. However, with reference to the bias rates from a previous CAM-Chem/ $\mathrm{Hg}$ model evaluation (Lei et al., 2013b) and to the projected concentration level for each species, the uncertainty for the simulated concentration may not seriously affect the conclusions. The estimated bias rate for the CAM-Chem $/ \mathrm{Hg}$-simulated $\mathrm{Hg}(0)$ concentration (based on TGM evaluation) averaged over North America is 


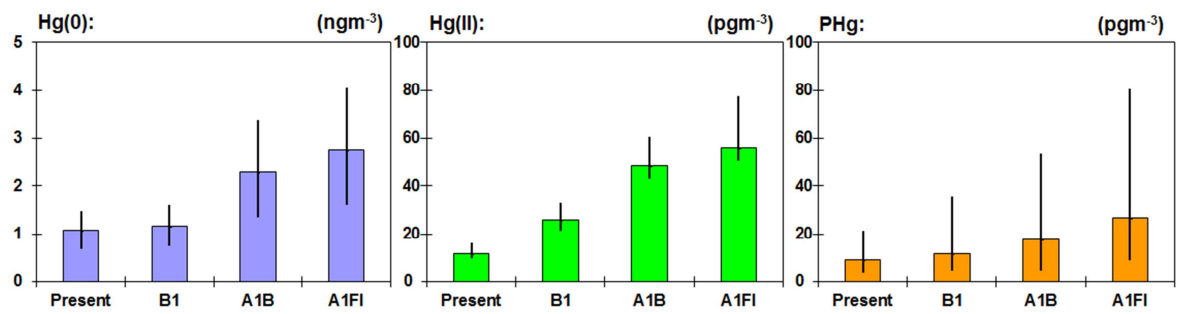

Fig. 7. Simulated annual mean concentrations of surface mercury species over the continental US for 2000 and for 2050 under the B1, A1B and A1FI scenarios considering both climate and emission changes. The columns show the averaged concentrations and the lines on the columns represent the range over the US.

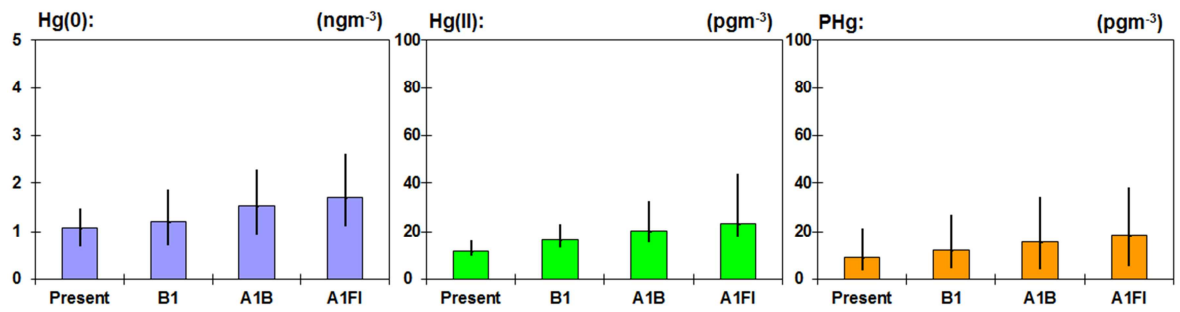

Fig. 8. Simulated annual mean concentrations of surface mercury species over the continental US for 2000 and for 2050 under the B1, A1B and A1FI scenarios considering climate change effects only. The columns show the averaged concentrations and the lines on the columns represent the range over the US.

less than $10 \%$ against the observations. The bias rate for wet deposition over the US is approximately $20 \%$, which can be used as the upper limit for the bias rate of $\mathrm{Hg}(\mathrm{II})$ in disregarding precipitation bias. Although the evaluation for $\mathrm{PHg}$ concentrations is not available, the bias rate for $\mathrm{PHg}$ is considered to be at the same level as $\mathrm{Hg}$ (II). Based on these rates, we use two decimal places for GEM changes and one decimal place for the others in Table 3 .

\section{Discussion and conclusions}

We have investigated the effects of projected global changes in climate and emissions on atmospheric mercury and on air quality in the US by using a global atmospheric mercury model (CAM-Chem/Hg). Owing to projected future socioeconomic and technology development, developed countries show a slow increase or even a decrease in future levels of mercury emissions, while developing countries show an increasing trend. Total mercury emissions are expected to increase by 2050. Anthropogenic mercury emissions in 2050 range between $2386.2 \mathrm{Mg} \mathrm{yr}^{-1}$ and $5983.7 \mathrm{Mg} \mathrm{yr}^{-1}$. For North America, total anthropogenic emissions are likely to decrease under the B1 scenario, although the rising temperature may increase natural emissions from land and ocean reservoirs. In all scenarios, the proportion of elemental mercury in emissions for 2050 decreases, while that of reactive gaseous mercury increases. Emissions from land and oceans in 2050 increase due to the accumulation of net mercury de- position in surface storage reservoirs. With projected changes in biomass burning and wildfires, mercury emissions from the former are estimated to be between $447 \mathrm{Mg} \mathrm{yr}^{-1}$ and $670 \mathrm{Mg} \mathrm{yr}^{-1}$. These findings imply that industrial development will significantly affect global mercury pollution. Developing countries will be the main contributors to likely net global atmospheric mercury increases in the coming decades. Controlling the use of industrial materials that contain mercury compounds and improving technologies to reduce the release of mercury into the environment would thus be effective ways to mitigate mercury pollution.

For 2050, the zonal average concentration of surface TGM over the mid-latitude in the Northern Hemisphere shows a potential increase of $0.5-2.3 \mathrm{ng} \mathrm{m}^{-3}$ above present levels. The zonal average concentrations of surface TGM in the tropics and mid-latitudes in the Southern Hemisphere increase by $0.5-1.2 \mathrm{ng} \mathrm{m}^{-3}$. Changes in TGM concentrations at high latitudes (above $60^{\circ}$ ) are less than half of the average changes in the corresponding hemisphere. This difference shows that the meridional gradient of TGM from the polluted low-to-mid-latitude to the less polluted high latitude will be larger in 2050 than it is today.

Mercury's influence on air quality in 2050 over the continental US was examined by assessing the individual and combined effects of climate and emissions changes. Climate change has a potential effect on the concentration of atmospheric elemental mercury of between 0.14 and $0.63 \mathrm{ng} \mathrm{m}^{-3}$, while the effect on the concentration of reactive gaseous mercury is $4.7-11.6 \mathrm{pg} \mathrm{m}^{-3}$. $\mathrm{PHg}$ concentrations will change by 
3.3-9.8 $\mathrm{pg} \mathrm{m}^{-3}$. Changes in anthropogenic emissions have relatively large effects on mercury species over the continental US. The potential effect on the concentration of atmospheric elemental mercury is $-0.04-1.05 \mathrm{ng} \mathrm{m}^{-3}$, while the effect on the concentration of reactive gaseous mercury is $9.55-33 \mathrm{pg} \mathrm{m}^{-3}$. The change in $\mathrm{PHg}$ concentrations is $-0.6-$ $8.0 \mathrm{pg} \mathrm{m}^{-3}$. The impact of emissions changes is relatively more significant than that of climate change on future atmospheric mercury. As a result, the future TGM concentration may increase by $2.1-4.0 \mathrm{ng} \mathrm{m}^{-3}$ for the eastern US and 1.4$3.0 \mathrm{ng} \mathrm{m}^{-3}$ for the western US in the A1FI scenario. Under the lower bound of potential climate warming (B1 scenario), TGM concentration does not show a significant change. The effect of climate change and remote emissions changes in surrounding areas is compensated by a domestic emissions decrease. Therefore, variation in mercury pollution is more sensitive to climate change than that for other pollutants (e.g., surface ozone), which may be mainly affected by changes in anthropogenic emissions (Lei et al., 2013a). More effort therefore needs to be placed on monitoring toxic mercury pollution in the future.

We also analyzed potential changes in the wet deposition of mercury over the continental US and found that mercury wet deposition increased in all three scenarios. Precipitation change and an increase in $\mathrm{Hg}$ (II) concentration may increase the amount of wet deposition. Annual wet deposition in 2050 may increase by $1-14 \mu \mathrm{g} \mathrm{m}^{-2}$ for the eastern US and $0-4 \mu \mathrm{g} \mathrm{m}^{-2}$ for the western US depending on projections in energy use. This result implies that more mercury from industrial emissions will be deposited into the water system and may further enter the ecosystem. Thus, we could experience a further challenge in mercury contamination by midcentury.

Acknowledgements. The research was supported in part by the US Environmental Protection Agency Science to Achieve Results (STAR) Program under award number EPA RD-83337301. The research was also supported by the National Research Council (NRC) Associateship Awards. The authors acknowledge DOE/NERSC and NCSA/UIUC for the supercomputing support. We appreciate D. Streets' work on $\mathrm{Hg}$ emissions projections and W. Luke's comments during the manuscript preparation. We also appreciate help from the editor and reviewers of this article. Their works significantly improve the quality of this article.

Edited by: J. W. Bottenheim

\section{References}

Aiuppa, A., Bagnato, E., Witt, M. L. I., Mather, T. A., Parello, F., Pyle, D. M., and Martin, R. S.: Real-time simultaneous detection of volcanic $\mathrm{Hg}$ and $\mathrm{SO}_{2}$ at La Fossa Crater, Vulcano (Aeolian Islands, Sicily), Geophys. Res. Lett., 34, L21307, doi:10.1029/2007GL030762, 2007.
AMAP: AMAP Assessment 2011: Mercury in the Arctic. Arctic Monitoring and Assessment Programme (AMAP), Oslo, Norway, xiv + 193 pp., 2011.

Bullock, R. and Brehme, K.: Atmospheric mercury simulation using the CMAQ model: formulation description and analysis of wet deposition results, Atmos. Environ., 36, 2135-2146, doi:10.1016/s1352-2310(02)00220-0, 2002.

Chand, D., Jaffe, D., Prestbo, E., Swartzendruber, P. C., Hafner, W., Weiss-Penzias, P., Kato, S., Takami, A., Hatakeyama, S., and Kajii, Y.: Reactive and particulate mercury in the Asian marine boundary layer, Atmos. Environ., 42, 7988-7996, 2008.

Cohen, M., Artz, R., Draxler, R., Miller, P., Poissant, L., Niemi, D., Ratte, D., Deslauriers, M., Duval, R., Laurin, R., Slotnick, J., Nettesheim, T., and McDonald, J.: Modeling the Atmospheric Transport and Deposition of Mercury to the Great Lakes, Environ. Res., 95, 247-265, 2004.

Cohen, M., Artz, R., and Draxler, R.: NOAA Report to Congress: Mercury Contamination in the Great Lakes, Air Resources Laboratory, Silver Spring MD, submitted to Congress on 14 May, 2007.

Cohen, M., Draxler, R., and Artz, R.: Modeling Atmospheric Mercury Deposition to the Great Lakes, Final Report for work conducted with FY2010 funding from the Great Lakes Restoration Initiative, NOAA Air Resources Laboratory, Silver Spring, MD, 16 December , 2011.

Corbitt, E. S., Jacob, D. J., Holmes, C. D., Streets, D. G., and Sunderland, E. M.: Global source-receptor relationships for mercury deposition under present-day and 2050 emissions scenarios, Environ. Sci. Technol., 45, 10477-10484, 2011.

Emmons, L. K., Walters, S., Hess, P. G., Lamarque, J.-F., Pfister, G. G., Fillmore, D., Granier, C., Guenther, A., Kinnison, D., Laepple, T., Orlando, J., Tie, X., Tyndall, G., Wiedinmyer, C., Baughcum, S. L., and Kloster, S.: Description and evaluation of the Model for Ozone and Related chemical Tracers, version 4 (MOZART-4), Geosci. Model Dev., 3, 43-67, doi:10.5194/gmd3-43-2010, 2010.

Ferrara, R., Mazzolai, B., Lanzillotta, E., Nucaro, E., and Pirrone, N.: Volcanoes as emission sources of atmospheric mercury in the Mediterranean basin, Sci. Total Environ., 259, 115-121, doi:10.1016/s0048-9697(00)00558-1, 2000.

Fisher, J. A., Jacob, D. J., Soerensen, A. L., Amos, H. M., Steffen, A., and Sunderland, E. M.: Riverine source of Arctic Ocean mercury inferred from atmospheric observations, Nat. Geosci., 5, 499-504, doi:10.1038/ngeo1478, 2012.

Holloway, T., Voigt, C., Morton, J., Spak, S. N., Rutter, A. P., and Schauer, J. J.: An assessment of atmospheric mercury in the Community Multiscale Air Quality (CMAQ) model at an urban site and a rural site in the Great Lakes Region of North America, Atmos. Chem. Phys., 12, 7117-7133, doi:10.5194/acp-12-71172012, 2012.

Holmes, C. D., Jacob, D. J., Mason, R. P., and Jaffe, D. A.: Sources and deposition of reactive gaseous mercury in the marine atmosphere, Atmos. Environ., 43, 2278-2285, 2009.

Holmes, C. D., Jacob, D. J., Corbitt, E. S., Mao, J., Yang, X., Talbot, R., and Slemr, F.: Global atmospheric model for mercury including oxidation by bromine atoms, Atmos. Chem. Phys., 10, 12037-12057, doi:10.5194/acp-10-12037-2010, 2010.

Horowitz, L., Walters, S., Mauzerall, D.: Emmons, L., Rasch, P., Granier, C., Tie, X., Lamarque, J-F., Schultz, M., and Tyndall, 
G.: A global simulation of tropospheric ozone and related tracers: Description and evaluation of MOZART, version 2, J. Geophys. Res., 108, 4784, doi:10.1029/2002JD002853, 2003.

IPCC: Intergovernmental Panel on Climate Change: Atmospheric chemistry and greenhouse gases, in: Climate Change 2001: The Scientific Basis, edited by: Houghton, J. T., Ding, Y., Griggs, D. J., Noguer, M., van der Linden, P. J., Dai, X., Maskell, K., and Johnson, C. A., Cambridge Univ. Press, New York, 239-288, 2001.

IPCC: Intergovernmental Panel on Climate Change: IPCC Special Report on Emissions Scenarios, Cambridge University Press, 2004.

IPCC: Intergovernmental Panel on Climate Change: IPCC Fourth Assessment Report: Climate Change 2007 (AR4), Cambridge, United Kingdom and New York, NY, USA. Cambridge University Press, 2007.

Jaffe, D. A., Prestbo, E., Swartzendruber, P., Weiss-Penzias, P., Kato, S., Takami, A., Hatakeyama, W., and Kajii, Y.: Export of atmospheric mercury from Asia, Atmos. Environ., 39, 30293038, 2005.

Lamarque, J.-F., Emmons, L. K., Hess, P. G., Kinnison, D. E., Tilmes, S., Vitt, F., Heald, C. L., Holland, E. A., Lauritzen, P. H., Neu, J., Orlando, J. J., Rasch, P. J., and Tyndall, G. K.: CAM-chem: description and evaluation of interactive atmospheric chemistry in the Community Earth System Model, Geosci. Model Dev., 5, 369-411, doi:10.5194/gmd-5-369-2012, 2012.

Lee, H., Olsen, S. C., Wuebbles, D. J., and Youn, D.: Impacts of aircraft emissions on the air quality near the ground, Atmos. Chem. Phys., 13, 5505-5522, doi:10.5194/acp-13-5505-2013, 2013.

Lei, H., Wuebbles, D. J., and Liang, X.-Z.: Projected risk of high ozone episodes in 2050, Atmos. Environ., 59, 567-577, doi:10.1016/j.atmosenv.2012.05.051, 2012.

Lei, H., Wuebbles, D. J., Liang, X.-Z., and Olsen, S.: Domestic versus international contributions on 2050 ozone air quality: How much is convertible by regional control?, Atmos. Environ., 68, 315-325, doi:10.1016/j.atmosenv.2012.12.002, 2013 a.

Lei, H., Liang, X.-Z., Wuebbles, D. J., and Tao, Z.: Model analyses of atmospheric mercury: present air quality and effects of transpacific transport on the United States, Atmos. Chem. Phys., 13, 10807-10825, doi:10.5194/acp-13-10807-2013, 2013 b.

Lin, C.-J., Shetty, S. K., Pan, L., Pongprueksa, P., Jang, C., and Chu, H-W.: Source Attribution for Mercury Deposition in the Contiguous United States: Regional Difference and Seasonal Variation, J. Air Waste Ma., 62, 52-63, 2011.

Lindberg, S., Hanson, P., Meyers, T., and Kim, K.-H.: Air/surface exchange of mercury vapor over forests - The need for a reassessment of continental biogenic emissions, Atmos. Environ., 32, 895-908, doi:10.1016/S1352-2310(97)00173-8, 1998.

NADP: National Atmospheric Deposition Program: Annual data summaries, http://nadp.sws.uiuc.edu/lib/dataReports.aspx (last access: December 2012), 2008.

Nriagu, J. and Becker, C.: Volcanic emissions of mercury to the atmosphere: global and regional inventories, Sci. Total Environ., 304, 3-12, 2003.

Pacyna, E., Pacyna, J., Steenhuisen, F., and Wilson, S.: Global anthropogenic mercury emission inventory for 2000, Atmos. Environ., 40, 4048-4063, 2006.
Pan, L., Carmichael, G. R., Adhikary, B., Tang, Y., Streets, D., Woo, J-H., Friedli, H. R., and Radke, L. F.: A regional analysis of the fate and transport of mercury in East Asia and an assessment of major uncertainties, Atmos. Environ., 42, 1144-1159, 2008.

Pan, L., Lin, C.-J., Carmichael, G. R., Streets, D. G., Tang, Y., Woo, J.-H., Shetty, S. K., Chu, H.-W., Ho, T. C., Friedli, H. R., and Feng, X.: Study of atmospheric mercury budget in East Asia using STEM-Hg modeling system, Sci. Total Environ., 408, $3277-$ 3291, 2010.

Poissant, L. and Casimir, A.: Water-air and soil-air exchange rate of total gaseous mercury measured at background sites, Atmos. Environ., 32, 883-893, 1998.

Pyle, D. and Mather, T.: The importance of volcanic emissions for the global atmospheric mercury cycle, Atmos. Environ., 37, 5115-5124, 2003.

RIVM: The IMAGE 2.2 implementation of the SRES scenarios; A comprehensive analysis of emissions, climate change and impacts in the 21 st century, RIVM CD-ROM publication 481508018, Bilthoven, the Netherlands, National Institute for Public Health and the Environment, 2001.

Rutter, A. P., Shakya, K. M., Lehr, R., Schauer, J. J., and Griffin, R. J.: Oxidation of gaseous elemental mercury in the presence of secondary organic aerosols, Atmos. Environ., 59, 86-92, 2012.

Selin, N., Jacob, D., Park, R., Yantosca, R., Strode, S., Jaeglé, L., and Jaffe, D.: Chemical cycling and deposition of atmospheric mercury: Global constraints from observations, J. Geophys. Res., 112, D02308, doi:10.1029/2006JD007450, 2007.

Selin, N., Jacob, D., Yantosca, R., Strode, S., Jaeglé, L., and Sunderland, E.: Global 3-D land-ocean-atmosphere model for mercury: Present-day versus preindustrial cycles and anthropogenic enrichment factors for deposition, Global Biogeochem. Cy., 22, 1-13, doi:10.1029/2007GB003040, 2008.

Smith-Downey, N., Sunderland, E., and Jacob, D.: Anthropogenic impacts on global storage and emissions of mercury from terrestrial soils: insights from a new global model , J. Geophys. Res., 115, G03008, doi:10.1029/2009JG001124, 2010.

Soerensen, A., Skov, H., Jacob, D., Soerensen, B., and Johnson, M.: Global concentrations of gaseous elemental mercury and reactive gaseous mercury in the marine boundary layer, Environ. Sci. Technol., 44, 7425-7430, 2010.

Streets, D., Hao, J., Wu, Y., Jiang, J., Chan, M., Tian, H., and Feng, X.: Anthropogenic mercury emissions in China, Atmos. Environ., 39, 7789-7806, 2005.

Streets, D., Zhang, Q., and Wu, Y.: Projections of global mercury emissions in 2050, Environ. Sci. Technol., 43, 2983-2988, doi:10.1021/es802474j, 2009.

Strode, S., Jaegle, L., Selin, N., Jacob, D., Park, R., Yantosca, R., Mason, R., and Slemr, F.: Air-sea exchange in the global mercury cycle, Global Biogeochem. Cy., 21, GB1017, doi:10.1029/2006GB002766, 2007.

Tie, X., Brasseur, G., Emmons, L., Horowitz, L., and Kinnison, D.: Effects of aerosols on tropospheric oxidants: A global model study, J. Geophys. Res., 106, 22931-22964, 2001.

Tie, X., Madronich, S., Walters, S., Edwards, D., Ginoux, P., Mahowald, N., Zhang, R., Lou, C., and Brasseur, G.: Assessment of the global impact of aerosols on tropospheric oxidants, J. Geophys. Res., 110, D03204, doi:10.1029/2004JD005359, 2005. 
Timonen, H., Ambrose, J. L., and Jaffe, D. A.: Oxidation of elemental $\mathrm{Hg}$ in anthropogenic and marine airmasses, Atmos. Chem. Phys., 13, 2827-2836, doi:10.5194/acp-13-2827-2013, 2013.

UNEP: The Global Atmospheric Mercury Assessment: Sources, Emissions and Transport, UNEP Chemicals Branch, Geneva, Switzerland, 2008.

UNEP: Global Mercury Assessment 2013: Sources, Emissions, Releases and Environmental Transport, UNEP Chemicals Branch, Geneva, Switzerland, 2013.

USEPA: EPA's Roadmap for Mercury, available at: http://www.epa.gov/mercury/archive/roadmap/pdfs/

FINAL-Mercury-Roadmap-6-29.pdf (last access: 1 March 2013), 2006.

USGS : Glacial Ice Cores Reveal A Record of Natural and Anthropogenic Atmospheric Mercury Deposition for the Last 270 Years, US Geological Survey, 2007.
Wängberg, I., Schmolke, S., Schager, P., Munthe, J., Ebinghaus, R., and Iverfeldt, A.: Estimates of air-sea exchange of mercury in the Baltic Sea, Atmos. Environ., 35, 5477-5484, 2001.

Witt, M., Mather, T., Pyle, D., Aiuppa, A., Bagnato, E., and Tsanev, V. I.: Mercury and halogen emissions from Masaya and Telica volcanoes, Nicaragua, J. Geophys. Res.-Sol. Ea., 113, B06203, doi:10.1029/2007JB005401, 2008.

Wu, S., Mickley, L., Leibensperger, E., Jacob, D., Rind, D., and Streets, D.: Effects of 2000-2050 global change on ozone air quality in the United States, J. Geophys. Res., 113, D06302, doi:10.1029/2007JD008917, 2008.

Zhang, H., Lindberg, S., Marsik, F., and Keeler, G.: Mercury air/surface exchange kinetics of background soils of the Tahquamenon River watershed in the Michigan Upper Peninsula, Water Air Soil Poll., 126, 151-169, 2011. 